\title{
HUBUNGAN ANTARA KEPERCAYAAN DIRI DENGAN KECEMASAN SOSIAL PADA NARAPIDANA MENJELANG BEBAS DI LEMBAGA PEMAYARAKATAN KLAS IIA MUARO PADANG
}

\author{
Darma Syahrullah Ekajaya,Jufriadi \\ Universitas Putra Indonesia "YPTK" Padang \\ darmasyahrullahekajaya@gmail.com,jufriadi5858@gmail.com
}

\begin{abstract}
This study aims to find out and understand self-confidence with social anxiety before free prisoners at Muaro Padang IIA Class Correctional Institution. Variable Dependent in this study is self-confidence and the independent variable is social anxiety. This research is a population research. The sample in this study is prisoners who are free under the guidance of Muaro Padang Class IIA Correctional Institution, which amounts to 72 people. The research method used is quantitative research methods. Measuring instruments used are the self-confidence scale and social anxiety scale, then the data are analyzed using Pearsoncorrelation techniques Product Momentand interpreted based on theories related to the research variables. The results of this study are based on aspects - Aspects of Self Confidence according to Ghufron and Risnawita (2014) and aspects of Social Anxiety according to La Greca and Lopez (1998). Test of validity and reliability usingtechnique Cronbach's Alpha. The results of the validity coefficient on the self-confidence scale ranged from 0.300 to 0.643 , while the reliability coefficient was 0.899 . The results of the validity coefficient on the social anxiety scale ranged from 0.348 to 0.843 , while the reliability coefficient was 0.916 . The results of data analysis showed the magnitude of the correlation coefficient of -0.627 with a significant level of $p=0.000(p<0.01)$ with an effective contribution of $39 \%$ and the remaining $61 \%$ was influenced by other factors. This means that there is a negative relationship between confidence in prisoners' social anxiety before being free under the guidance of Muaro Padang Class IIA Correctional Institution.
\end{abstract}

Keywords: Self Confidence, Social Anxiety, Prisoners

\begin{abstract}
ABSTRAK
Penelitian ini bertujuan untuk mengetahui dan memahami kepercayaan diri dengan kecemasan sosial narapidana menjelang bebas di Lembaga Pemasyarakatan Klas IIA Muaro Padang.Variabel Dependen pada penelitian ini adalah kepercyaan diri dan variabel independen adalah kecemasan sosial. Penelitian ini merupakan penelitian populasi,Sampel dalam penelitian ini adalah narapidana menjelang bebas di bawahpembinaan Lembaga Pemasyarakatan Klas IIA Muaro Padang yang berjumlah 72 orang. Metode penelitian yang digunakan adalah metode penelitian kuantitatif.Alat ukur yang digunakan adalah skala kepercayaan diri dan skala kecemasan sosial, kemudian data tersebut dianalisis dengan menggunakan teknik korelasi Product Moment Pearsondan diinterpretasikan berdasarkan teori yang berhubungan dengan variabel penelitian.Hasil dari penelitian ini dilihat berdasarkan aspek-aspek Kepercayaan Diri menurut Ghufron dan Risnawita (2014) dan aspek-aspek Kecemasan Sosial menurut La Greca dan Lopez (1998).Uji validitas dan reliabilitas menggunakan teknik Alpha Cronbach. Hasil koefisien validitas pada skala kepercayaan diri berkisar dari 0,300 sampai dengan 0,643, sedangkan koefisien reliabilitasnya sebesar 0,899. Hasil koefisien validitas pada skala kecemasan sosial berkisar dari 0,348 sampai dengan 0,843 , sedangkan koefisien reliabilitasnya sebesar 0,916 . Hasil analisis data menunjukkan besarnya koefisien korelasi sebesar -0,627 dengan taraf signifikan $\mathrm{p}=0,000(\mathrm{p}<0,01)$ dengan sumbangan efektif $39 \%$ sisanya $61 \%$ dipengaruhi oleh faktor lain. Artinya ada hubungan yang negatif antara kepercayaan diri dengan kecemasan sosial narapidana menjelang bebas di bawah pembinaan Lembaga Pemasyarakatan Klas IIA Muaro Padang.
\end{abstract}

Kata Kunci : Kepercayaan Diri, Kecemasan Sosial, Narapidana 


\section{PENDAHULUAN}

Lembaga Pemasyarakatan adalah tempat untuk melaksanakan pembinaan narapidana dan anak didik pemasyarakatan (UU RI No. 12 Th. 1995 tentang Pemasyarakatan Pasal 1 ayat 2). Lembaga pemasyarakatan pada dasarnya bukan sebagai muara akhir dari seluruh tindak kejahatan yang ditangani oleh Sistem Peradilan Pidana Indonesia. Namun Lembaga Pemasyarakatan adalah sebuah lembaga yang diselenggarakan oleh pemerintah untuk memberi wadah dan membina narapidana agar mereka mempunyai cukup bekal guna menyongsong kehidupan setelah selesai menjalani masa pidana. Selain itu, Lembaga Pemasyarakatan merupakan suatu pengejawantahan keadilan yang bertujuan untuk mencapai reintegrasi sosial atau pulihnya suatu hubungan antara Warga Binaan Lembaga Pemasyarakatan (Hmibecak dalam Astuti, 2008). Lembaga pemasyarakatan sebagai wadah pembinaan bagi para narapidana bertujuan untuk mengembalikan fungsi seorang narapidana agar dapat kembali hidup normal di tengah masyarakat setelah menjalani masa hukumannya (Andriawati, 2012).

Menurut Widagdo (dalam Nugroho, 2015) narapidana adalah orang yang melakukan tindak pidana dan sedang menjalani pidana atau hukuman dalam penjara. Menurut data dari kepolisian daerah pada tahun 2011 di seluruh provinsi di Indonesia tercatat sebanyak 347.605 jumlah tindak pidana di seluruh provinsi di Indonesia (Badan Pusat statistik, 2012). Untuk daerah Sumatera Barat pada tahun 2011 tercatat 11.695 kasus tindak pidana (BPS, 2012). Di kota Padang tercatat sekitar 6.518 kasus tindak pidana dalam tahun 2013 (Metro Padang, 2013). Adapun tindak pidana yang dilakukan biasanya berupa pembunuhan, penculikan, penganiayaan, pencurian, kejahatan seksual, pemalsuan, perjudian, penyalahgunaan napza, dan lain-lain (Vaeroy, dalam Putri dkk, 2014). Di Lembaga Pemasyarakatan Klas IIA Muaro Padang, penghuni yang tercatat per tanggal 25 April 2017 sebanyak 1376 orang dengan rincian 1038 orang narapidana dan 338 orang tahanan.

Para narapidana yang dianggap sebagai orang-orang yang ditempatkan di Lembaga Pemasyarakatan justru mengalami problem psikologis karena terdorong rasa bersalah, kemudian dikucilkan dalam masyarakat, resah dan cemas (Astuti, 2008). Kartono (dalam Zuhro, 2011) mengatakan bahwa pemenjaraan yang terjadi pada narapidana seringkali memunculkan rasa rendah diri dan minimnya kontak dengan dunia luar.

Dalam menjalani masa pidananya, narapidana akan diberikan pembinaan. Menurut Keputusan Menteri Kehakiman RI No. M.02-PK.04.10 Tahun 1990 tentang Pola Pembinaan Narapidana / Tahanan (dalam Astuti, 2008) disebutkan pembinaan terhadap narapidana dimaksudkan untuk memberikan bekal kepada narapidana sehingga kelak tidak akan melakukan pengulangan pelanggaran hukum serta dapat berguna bagi masyarakat dan mampu memperoleh kebahagiaan di dunia dan di akhirat kelak. Kegiatan pembinaan di Lembaga Pemasyarakatan mencakup proses pembinaan kepribadian dan pembinaan kemandirian. Pembinaan kepribadian meliputi: Pembinaan kesadaran beragama, pembinaan kesadaran berbangsa dan bernegara, pembinaan kemampuan intelektual (kecerdasan), pembinaan mengintegrasikan dengan masyarakat. Adapun pembinaan kemandirian meliputi: pembinaan untuk mendukung usahausaha mandiri, misalnya kerajinan tangan, industi rumah tangga; keterampilan untuk mendukung usaha-usaha industri kecil, misalnya pembuatan batako; keterampilan yang disesuaikan dengan bakatnya masing-masing, misalnya keterampilan seni (band, seni tari); keterampilan untuk mendukung usaha-usaha industri atau kegiatan pertanian dengan menggunakan teknologi madya atau tinggi, misalnya industri kulit.

Setelah narapidana bebas, mereka akan menghadapi tantangan yang berat, Indiyah (dalam Nugroho, 2015) menekankan bahwa meskipun bebas setelah menjalani masa hukuman di Lembaga Pemsyarakatan, tetapi mantan narapidana dihadapkan pada keadaan yang belum pasti. Menurut Al-Jauhar (dalam Nugroho, 2015) pandangan masyarakat mengenai mantan narapidana dipengaruhi oleh Lembaga Hukum dan Lembaga Pemasyarakatan di Indonesia yang tergolong lemah dan tidak tegas dalam menjalani fungsi hukum. 


\section{Darma Syahrullah Ekajaya,Jufriadi \\ Jurnal PSYCHE 165 Vol 12 No 1 (2019) 93-102}

Pandangan masyarakat mengenai mantan narapidana juga dipengaruhi oleh budaya masyarakat yang memandang kriminaliatas sebagai hal yang tabu. Pandangan masyarakat tersebut juga dilatarbelakangi oleh pengalaman pribadi, pengetahuan dan juga pengaruh media massa yang mengatakan bahwa mantan narapidana sebagai sumber permasalahan, sampah masyarakat, orang jahat, individu yang harus diwaspadai dan berpotensi melakukan kembali tindakan kriminal. Hal ini rentan menimbulkan kecemasan sosial bagi mantan narapidana.

Brecht (dalam Nainggolan, 2011) menjelaskan bahwa kecemasan sosial merupakan rasa takut dan khawatir yang berlebihan jika berada bersama dengan orang lain dan merasa cemas pada situasi sosial karena kekhawatir akan mendapat penilaian atau bahkan evaluasi dari orang lain, tetapi akan merasa baik ketika sedang sendirian. Kecemasan sosial merupakan suatu keadaan dimana adanya ketakutan ataupun kekhawatiran yang berlebihan terhadap situasi sosial sehingga membuat individu tersebut merasa cemas pada situasi sosial karena khawatir akan mendapat penilaian negatif dari orang lain yang membuat individu tersebut cenderung menghindari kegiatan sosial.

Rakhmat (dalam Prawoto, 2010) orang yang mengalami ketakutan dalam berinteraksi sosial akan menarik diri dari pergaulan, berusaha sekecil mungkin berkomunikasi, dan akan berkomunikasi bila terdesak. Jika ia berkomunikasi, sering pembicaraannya tidak relevan, sebab berbicara yang relevan tentu akan mengundang reaksi orang lain dan ia dituntut berbicara lagi. Memang tidak semua ketakutan berkomunikasi disebabkan kurangnya percaya diri, tetapi di antara berbagai faktor yang ada, percaya diri adalah yang paling menentukan.

Narapidana dapat membangun kepercayaan dirinya dalam menghadapi kehidupan setelah hukuman pidana selesai dan kembali ke lingkungan masyarakat. Menurut Fatimah (dalam Rosita, 2012) percaya diri adalah sikap positif seorang individu yang memampukan diri sendiri maupun terhadap lingkungan atau situasi yang dihadapinya. Kepercayaan diri berkembang melalui interaksi individu dengan lingkungannya. Lingkungan psikologis dan sosiologis akan menumbuhkan dan meningkatkan kepercayaan diri seseorang. Kepercayaan diri merupakan salah satu koping individu untuk menghadapi tekanan, dan tuntutan yang dapat menyebabkan stres, dengan kepercayaan diri individu akan mempunyai keyakinan dan keberanian untuk dapat secara efektif menghadapi peristiwa yang kurang nyaman bagi individu (Ernawati dkk, 2012).

Lauster (dalam Ghufron dan Risnawati, 2014) menyatakan bahwa kepercayaan diri merupakan suatu sikap atau perasaan yakin atas kemampuan diri sendiri sehingga orang yang bersangkutan tidak terlalu cemas dalam tindakan-tindakannya, dapat merasa bebas untuk melakukan hal - hal yang disukainya dan bertanggung jawab atas perbuatannya hangat dan sopan dalam berinteraksi dengan orang lain, dapat menerima dan menghargai orang lain, memiliki dorongan untuk berprestasi serta dapat mengenal kelebihan dan kekurangannya.

Penelitian Nainggolan (2011) menyimpulkan bahwa terdapat hubungan dengan arah negatif antara kepercayaan diri dengan kecemasan sosial. Hasil koefisien korelasi dengan arah negatif menunjukkan bahwa semakin tinggi kepercayaan diri maka kecemasan sosial semakin rendah. Begitu pula sebaliknya, semakin rendah kepercayaan diri, maka kecemasan sosial akan semakin tinggi.

Orang dengan kepercayaan diri yang rendah akan menghindari situasi-situasi dimana individu tersebut dapat dilihat maupun diperhatikan oleh orang lain yang memungkinkan akan mendapatkan penilaian ataupun kritikan. Sehingga individu yang memiliki kepercayaan diri yang rendah cenderung mengalami kecemasasn sosial dan menghindari situasi-situasi sosial dimana mereka akan mendapatkan perhatian, penilaian, ataupun kritikan dari orang lain.Sebaliknya, individu yang memiliki kepercayaan diri yang baik akan memiliki rasa positif terhadap diri sendiri, dan percaya pada kemampuan diri sendiri sehingga individu tersebut dapat menjalani kehidupannya dengan baik sehingga terhindar dari kecemasan sosial (Mayestika dalam Anggraini, 2015).

Berdasarkan hasil wawancara terhadap 5 orang subjek (dengan sisa hukaman 2 bulan 1 orang, 4 bulan 3 orang dan 6 bulan 1 orang) yang merupakan narapidana di Lembaga Pemasyarakatan Klas IIA Muaro Padang dengan kasus pelecehan seksual (2 orang) dan pencurian (3 orang). Selama menjalani hukumannya, subjek cukup aktif dalam mengikuti 


\section{Darma Syahrullah Ekajaya,Jufriadi \\ Jurnal PSYCHE 165 Vol 12 No 1 (2019) 93-102}

serangkaian pembinaan yang ada, Lembaga Permayarakatan menyediakan program pembinaan kepada narapidana yang meliputi pembinaan kepribadian dan pembinaan kemandirian, yang dapat menumbuhkan kepercayaan diri narapidana untuk menghadapi kehidupan setelah bebas nanti. Namun subjek cenderung mengasingkan diri atau kurang bersosialisasi dengan orang lain. Dengan masa hukuman subjek yang menyisakan beberapa bulan lagi, subjek sering kali merasa khawatir mengenai bagaimana perlakuan masyarakat terhadap dirinya dengan statusnya sebagai mantan narapidana setelah subjek bebas nanti. Subjek memiliki ketidakyakinan dengan dirinya apakah masyarakat dapat menerima subjek kembali untuk menjadi bagian dari kehidupan sosial di lingkungan tersebut. Subjek berpendapat bahwa mantan narapidana atau residivis, akan sulit untuk diterima dimasyarakat, karena menurut pandangan subjek mantan narapidana atau residivis memiliki citra yang buruk karena pernah melakukan tindakan kriminal dan hanya akan menjadi aib keluarga.

Berdasarkan fenomena yang telah dikemukakan di atas, maka peneliti tertarik mengangkat judul penelitian yaitu "Hubungan Antara Kepercayaan Diri Dengan Kecemasan Sosial Pada Narapidana Menjelang Bebas Di Lembaga Pemasyarakatan Klas IIA Muaro Padang".

\section{LANDASAN TEORI}

\section{A. KECEMASAN SOSIAL}

\section{Pengertian Kecemasan Sosial}

Gümüs (dalam Baltaci dan Hamarta, 2013) mendefinisiskan kecemasan sosial adalah keadaan ketidaknyamanan dan stres bahwa pengalaman individu dengan ekspektasi bahwa dia akan bertindak tidak tepat, membuat bodoh dirinya sendiri, meninggalkan kesan negatif dan dievaluasi oleh orang lain dalam cara negatif (bodoh, pecundang, tidak kompeten, dan sebagainya) di berbagai acara maupun situasi sosial. Kecemasan sosial ditandai dengan rasa takut yang berlebihan sedang diteliti oleh orang lain dan menghindari kegiatan sosial yang membangkitkan rasa takut ini (Hedman, et al, dalam Anggraini 2015).

La Grace dan Lopez (1998) mengungkapkan kecemasan sosial adalah ketakutan yang menetap terhadap situasi sosial dan menghadapi evaluasi dari orang lain, diamati, takut dipermalukan dan dihina. Menurut Sternberg (dalam Swasti dan Martani, 2013) kecemasan sosial meningkat menjadi gangguan bila; pertama, tingkat kecemasan yang dialami semakin irasional dan mengganggu efektivitas kegiatan seharihari, kedua, justifikasi terhadap kecemasan berlebihan, misalnya individu merasakan tingkat kecemasan tinggi tanpa stimulus pemicu, dan ketiga, konsekuensi dari kecemasan tersebut membawa dampak negatif menyeluruh dalam hidup individu.

Berdasarkan uraian diatas, dapat disimpulkan bahwa kecemasan sosial merupakan suatu keadaan dimana adanya ketakutan ataupun kekhawatiran yang berlebihan terhadap situasi sosial sehingga membuat individu tersebut merasa cemas pada situasi sosial karena khawatir akan mendapat penilaian negatif dari orang lain yang membuat individu tersebut cenderung menghindari kegiatan sosial.

\section{B. Faktor-Faktor Yang Mempengaruhi Kecemasan Sosial}

Rapee (dalam Nainggolan, 2011) menjelaskan beberapa faktor-faktor tersebut seperti, (a) thinkingstyle (cara berpikir); (b) focusing attention(fokus perhatian), dan (c) avoidance (penghindaran). Selain itu Butler (dalam Anggraini, 2015) menyebutkan salah satu faktor yang dapat mempengaruhi kecemasan sosial adalah kepercayaan diri. Individu dengan kecemasan sosial akan merasa minder dan tidak mau bergaul dengan orang lain karena merasa bahwa orang lain tidak menyukainya dan berpikir bahwa orang lain berpikiran negatif tentang dirinya.

Menurut Durand (dalam Prawoto, 2010) ada tiga faktor yang menyebabkan seseorang mengalami kecemasan sosial yaitu :

a. Seorang dapat mewarisi kerentanan biologis menyeluruh untuk mengembangkan kecemasan atau kecenderungan biologis untuk menjadi sangat terhambat secara sosial. 


\section{Darma Syahrullah Ekajaya,Jufriadi \\ Jurnal PSYCHE 165 Vol 12 No 1 (2019) 93-102}

Eksistensi kerentanan psikologis menyeluruh seperti tercermin pada perasaan atas berbagaiperistiwa, khususnya peristiwa yang sangat menimbulkan stres, mungkin tidak dapat dikontrol dan dengan demikian akan mempertinggi kerentanan individu.

b. Ketika dalam keadaan stres, seseorang mungkin mengalami serangan panik yang tak terduga pada sebuah situasi sosial yang selanjutnya akan dikaitkan (dikondisikan) dengan stimulus-stimulus sosial. Individu kemudian akan menjadi sangat cemas tentang kemungkinan untukmengalami alarm (serangan panik) lain (yang dipelajari) ketika berada dalam situasisituasi sosial yang sama atau mirip.

c. Seseorang mungkin mengalami sebuah trauma sosial, riil yang menimbulkanalarm aktual. Kecemasan lalu berkembang (terkondisi) di dalam situasi-situasisosial yang sama atau mirip. Pengalaman sosial yang traumatik mungkin jugameluas kembali ke masa-masa sulit di masa kanak-kanak. Pengalaman ini dapat menghasilkankecemasan dan panik yang direproduksi di dalam situasi-situasi sosial di masamendatang.

Dari penjelasan mengenai faktor-faktor yang dapat mempengaruhi kecemasan sosial, dapat disimpulkan bahwa faktor-faktor yang dapat mempengaruhi kecemasan sosial yaitu faktor internal, dimana faktor ini disebabkan muncul dari dalam diri individu tersebut seperti kurang percaya diri, pengalaman traumatik, stres maupun frustasi dan faktor eksternal yang disebabkan oleh lingkungan seperti rendahnya dukungan sosial yang diterima individu tersebut.

\section{Aspek-aspek Kecemasan Sosial}

La Greca dan Lopez (1998) mengemukakan ada tiga aspek kecemasan sosial yaitu :

a. Ketakutan akan evaluasi negatif.

b. Penghindaran sosial dan rasa tertekan dalam situasi yang baru/berhubungan dengan orang asing/baru.

c. Penghindaran sosial dan rasa tertekan yang dialami secara umum/dengan orang yang dikenal.

Pendapat lain dari Ozbay dan Palanci (dalam Baltaci dan Hamarta, 2013) mengemukakan terdapat tiga aspek kecemasan sosial yaitu:

a. Penghindaran pada situasi-situasi sosial.

b. Kecemasan bahwa ia akan dikritik oleh orang lain.

c. Perasaan diri bahwa ia tidak berharga.

Dari pendapat di atas dapat disimpulkan aspek-apek kecemasan sosial adalah ketakutan akan evaluasi negatif, penghindaran sosial dan rasa tertekan dalam situasi yang baru/berhubungan dengan orang asing/baru, dan penghindaran sosial dan rasa tertekan yang dialami secara umum/dengan orang yang dikenal.

\section{KEPERCAYAAN DIRI}

\section{Pengertian Kepercayaan Diri}

Lauster (dalam Ghufron dan Risnawati, 2014) berpendapat bahwa kepercayaan diri merupakan salah satau aspek kepribadian yang berupa keyakinan akan kemampuan diri seseorang sehingga tidak terpengaruh oleh orang lain dan dapat bertindak sesuai kehendak, gembira, optimis, cukup toleran, dan bertanggung jawab.

Kepercayaan diri menurut Sarastika (dalam Puspitasari, 2014) adalah keyakinan atas kemampuan diri sendiri serta memiliki pengharapan yang realitas, bahkan ketika harapan mereka tidak terwujud, mereka tetap berpikiran positif dan dapat menerimanya.Balke (dalam Nainggolan, 2011) mendefinisikan kepercayaan diri sebagai kemauan seseorang untuk melakukan sesuatu yang paling menakutkan bagi dirinya dan meyakini bahwa dirinya mampu mengelola apapun yang timbul. Artinya bahwa kepercayaan diri dapat dikaitkan dengan kemampuan atau keberanian dalam mengambil resiko, keputusan, maupun tantangan yang bukan hanya membawa resiko fisik melainkan juga resiko psikologis karena timbul perasaan yang pasti tentang dirinya. 


\section{Darma Syahrullah Ekajaya,Jufriadi \\ Jurnal PSYCHE 165 Vol 12 No 1 (2019) 93-102}

Dari penjabaran diatas dapat disimpulkan bahwa kepercayaan diri merupakan suatu kemampuan atau keyakinan terhadap diri sendiri bahwa ia mampu mengembangkan kemampuannya, dapat memahami kekurangan dan kelebihan diri sendiri sehingga ia mampu mengatasi setiap masalah yang dihadapi dengan baik.

\section{E. Faktor-faktor Yang Mempengaruhi Kepercayaan Diri}

Ghufron dan Risnawati (2014) mengemukakan beberapa faktor yangmempengaruhi kepercayaan diri, yaitu:

a. Konsep Diri

Terbentuknya kepercayaan diri pada diri seseorang diawali perkembangan konsep diri yang diperoleh dalam pergaulannya dalam suatu kelompok. Hasil interaksi yang terjadi akan menghasilkan konsep diri.

b. Harga Diri

Konsep diri yang positif akan membentuk harga diri yang positif pula. Harga diri adalah penilaian yang dilakukan terhadap diri sendiri.

c. Pengalaman

Pengalaman dapat menjadi faktor munculnya rasa percaya diri dan menurunnya rasa percaya diri.

d. Pendidikan

Tingkat pendidikan seseorang akan berpengaruh terhadap tingkat kepercayaan diri seseorang. Tingkat pendidikan yang rendah akan menjadikan orang tersebut tergantung dan berada di bawah kekuasaan orang lain yang lebih pandai darinya. Sebaliknya, orang yang mempunyai pendidikan tinggi akan memiliki tingkat kepercayaan diri yang lebih dibandingkan yang berpendidikan rendah.

Berdasarkan pendapat di atas dapat ditarik kesimpulan bahwa faktor-faktor yang mempengaruhi kepercayaan diri adalah konsep diri, harga diri, pengalaman dan pendidikan. Faktor-faktor tersebut juga dipengaruhi oleh interaksi sosial maupun dari dalam diri individu tersebut.

\section{F. Aspek-aspek Kepercayaan Diri}

Lauster (dalam Ghufron dan Risnawati, 2014) mengemukakan aspek - aspek kepercayaan diri, yaitu:

a. Keyakinan kemampuan sendiri

Keyakinan kemampuan diri adalah sikap positif seseorang tentang dirinya. Ia mampu secara sungguh-sungguh akan apa yang dilakukannya.

b. Optimis

Sikap positif yang dimiliki seseorang yang selalu berpandangan baik dalam menghadapi segala hal tentang diri dan kemampuannya.

c. Objektif

Orang yang memandang permasalahan atau sesuatu sesuai dengan kebenaran yang semestinya, bukan menurut kebenaran pribadi atau menurut dirinya sendiri.

d. Bertanggung jawab

Bertanggung jawab adalah kesediaan orang untuk menanggung segala sesuatu yang telah terjadi menjadi konsekuensinya.

e. Rasional dan realistis

Rasional dan realistis adalah analisis terhadapa suatu masalah, sesuatu hal, dan suatu kejadian dengan menggunakan pemikiran yang dapat diterima oleh akala dan sesuai dengan kenyataan.

Berdasarkan pendapat di atas dapat ditarik kesimpulan bahwa kepercayaan diri adalah sifat yang dimiliki seseorang yang memiliki aspek-aspek keyakinan diri, optimis, objektif, bertanggung jawab, rasional dan realistis. 


\section{METODE PENELITIAN}

Metode pada penelitian ini menggunakan metode kuantitatif.

Adapun variabel yang digunakan dalam penelitian ini adalah sebagai berikut :

1. VariabelDependent : Kepercayaan Diri

2. Variabel Independent : Kecemasan Sosial

Populasi adalah wilayah generalisasi yang terdiri dari obyek atau subyek yang mempunyai kualitas dan karakteristik tertentu yang ditetapkan oleh peneliti untuk dipelajari dan kemudian ditarik kesimpulannya (Sugiyono, 2013). Populasi dalam penelitian ini adalah seluruh narapidana menjelang bebas pada tanggal 19 Juni 2017 hingga 31 Desember 2017di Lembaga Pemayarakatan Klas IIA Muaro Padang yang berjumlah 72 orang narapidana. Penelitian ini dilakukan di Lembaga Pemayarakatan Klas IIA MuaroPadang yang beralamat didi Jalan Muara No. 42 Padang. Sampel adalah bagian dari jumlah dan karakteristik yang dimiliki oleh populasi tersebut (Sugiyono, 2013). Menurut Sugiyono teknik sampling adalah teknik yang digunakan untuk menentukan sampel dari populasi. Adapun teknik pengambilan sampel pada penelitian ini adalah sampling jenuh, yaitu teknik sampel bila semua anggota populasi digunakan sebagai sample. Pengambilan sampel dilakukan sesuai dengan pendapat (Sugiyono, 2013)yang menyatakan bahwa apabila subyek penelitian relatif kecil, maka lebih baik diambil semua, sehingga penelitiannya merupakan penelitian populasi. Maka sampel dalam penelitian ini adalah keseluruhan dari populasi sebanyak 72 orang narapidana. Skala yang peneliti sebarkan sebanyak 72 skala dan yang dapat diolah sebanyak 64 skala sedangkan 8 skala tidak kembali.

Validitas dalam penelitian ini menggunakan validitas isi (content validity) dan validitas konstruksi (construct validity) untuk mengetahui valid atau tidaknya suatu alat ukur dibantu dengan menggunakan kisi-kisi instrumen, atau matrik pengembangan instrumen dengan bantuan IBM SPSS versi 21.0. Sebagai kriteria pemilihan item berdasarkan korelasi item total, biasanya digunakan batasan koefisien korelasi item total, koefisien korelasi $\geq 0,30$ (Azwar, 2013).

Pengertian reliabilitas mengacu kepada kepercayaan atau konsistensi hasil ukur,yang mengandung makna seberapa tinggi kecermatan pengukuran. Koefisien reliabilitas $\left(\mathrm{r}_{\mathrm{xx}}{ }^{\prime}\right)$ berada dalam rentang angka dari 0 sampai dengan 1,00. Sekalipun bila koefisien reliablitas semakin tinggi mendekati angka 1,00 berarti pengukuran semakin reliable, namun dalam kenyataannya pengukuran psikologi koefisien sempurna yang mencapai angka $r_{x x}=1,00$ belum pernah dijumpai (Azwar, 2013).

Skala dalam penelitian ini dianalisis dengan menggunakan teknik korelasi Product Moment Pearson, yang merupakan salah satu teknik untuk mencari derajat keeratan atau keterkaitan pengaruh antara variabel independen dengan variabel dependen (Azwar, 2013).

Pada penelitian ini sebelum melakukan uji hipotesis terlebih dahulu dilakukan uji asumsi dengan menggunakan uji normalitas dan uji linearitas. Uji normalitas bertujuan untuk mengetahui apakah data dalam penelitian ini sudah terdistribusi sesuai dengan prinsip-prinsip distribusi normal agar dapat digeneralisasikan terhadap populasi.

\section{HASIL DAN PEMBAHASAN}

Berdasarkan uji validitas dan reliabilitas pada penelitian ini menggunakan teknikproduct moment dan Alpha Cronbach. Untuk skala Kepercayaan Dirikoefisien validitas ditetapkan $\geq 0,30$, sehingga diperoleh hasil dari jumlah item awal 50 pernyataan, gugur 17 item sehingga jumlah item yang valid dan reliabel adalah 33 item, dengan nilai corrected item-total correlation berkisar antara 0,300 sampai dengan 0,643 sedangkan koefisien reliabilitasnya sebesar 0,899 dan skala Motivasi Berprestasi koefisien validitas ditetapkan $\geq 0,30$, sehingga diperoleh hasil dari jumlah item awal 42 pernyataan, gugur 13 item sehingga jumlah item yang 


\section{Darma Syahrullah Ekajaya,Jufriadi \\ Jurnal PSYCHE 165 Vol 12 No 1 (2019) 93-102}

valid dan reliabel adalah 29 item, dengan nilai corrected item-total correlation berkisar antara 0,348 sampai dengan 0,843 sedangkan koefisien reliabilitasnya; sebesar 0,916.

\section{Uji Normalitas}

Hasil pengolahan data dengan menggunakan program komputer maka diperoleh hasil sebagai berikut:

Tabel 1

Uji Normalitas Sebaran Skala Kepercayaan diri dan Kecemasan

\begin{tabular}{|l|l|l|l|l|}
\hline \multicolumn{1}{|c|}{ Variabel } & KSZ & P & Sebaran \\
\hline rcayaan diri & 4 & .944 &, 335 & Normal \\
\hline masan sosial & 4 & .317 &, 062 & Normal \\
\hline
\end{tabular}

Berdasarkan tabel di atas, maka diperoleh nilai signifikansi pada Kepercayaan Diri diperoleh nilai signifikansi sebesar $\mathrm{p}=0,335$ dengan $\mathrm{KSZ}=0,944$, hasil tersebut menunjukan bahwa nilai $p>0,05$, artinya sebaran skala Kepercayaan Diri terdistribusi secara normal, sedangkan untuk skala Kecemasan Sosial sebesar $\mathrm{p}=0$,062 dengan $\mathrm{KSZ}=1,317$ hasil tersebut menunjukan bahwa nilai $\mathrm{p}>0,05$, artinya sebaran skala Kecemasan Sosial terdistribusi secara normal.

\section{Uji Linieritas}

Uji linier dalam penelitian ini menggunakan analisis regresi yang diperoleh hasil sebagai berikut:

Tabel 2

Uji Linieritas

\begin{tabular}{|l|l|l|l|l|}
\hline $\mathbf{N}$ & $\mathbf{f}$ & Mean square & $\mathbf{F}$ & Sig \\
\hline 54 & & 3733,701 & 3,548 &, 000 \\
\hline
\end{tabular}

Berdasarkan tabel di atas, diperoleh nilai $\mathrm{F}=38,548$ dengan signifikansi sebesar $\mathrm{p}=$ $0,000(\mathrm{p}<0,05)$, artinya varians pada Skala Kecemasan Sosial dengan Kepercayaan Diritergolong linier.

\section{Uji Hipotesis}

Hasilpengolahan data mengenai hubungan antara kepercayaan diri dengan kecemasan sosial pada narapidana menjelang bebas di Lembaga Pemasyarakatan Klas IIA Muaro Padang, maka diperoleh hasil sebagai berikut:

Tabel 3

Uji Korelasi pearson antara kepercayaan diri dengan kecemasan

\begin{tabular}{|l|l|l|l|l|}
\hline $\mathrm{P}$ & $\alpha)$ & Nilai Korelasi $(\mathrm{r})$ & R square & \multicolumn{1}{c|}{ Kesimpulan } \\
\hline 000 & .01 & -0.627 & 0.393 & $\begin{array}{l}\text { 2-tailed) } 0,000<0,01 \text { level of } \\
\text { ficant }(\alpha), \text { berarti hipotesis } \\
\text { ma. }\end{array}$ \\
\hline
\end{tabular}

Berdasarkan tabel di atas, maka diperoleh koefisien korelasi antara variabel Kecemasan Sosialdan Kepercayaan Diri yaitu sebesar $r=-0,627$ dengan taraf signifikansi $p=0,000$. Hal ini menunjukkan adanya korelasi yang berarah negatif atau tidak searah antara kedua variabel tersebut, yang artinya jika Kepercayaan Dirinarapidana menjelang bebas di bawah pembinaan Lembaga Pemasyarakatan Klas IIA Muaro Padangtinggi, maka Kecemasan Sosial akan rendah dan sebaliknya jika Kepercayaan Diri narapidana menjelang bebas di bawah pembinaan Lembaga Pemasyarakatan Klas IIA Muaro Padangrendah, maka Kecemasan Sosialcenderung akan tinggi. Hal ini diperkuat dengan hasil uji signifikansi dengan bantuan SPSS versi 21.0 for windows, didapatkan $\mathrm{p}=0,000<0,01$ level of significant $(\alpha)$, dimana menurut Nugroho (2005) hipotesis diterima, yang berarti terdapat hubungan yang signifikan antara Kepercayaan Diridengan Kecemasan Sosial pada narapidana menjelang bebas di bawah pembinaan Lembaga Pemasyarakatan Klas IIA Muaro Padang.

Berikut tabel deskriptif statisitik dari variabel Adversity Qoutient Dan Motivasi Berprestasi berdasarkan mean empirik. 
Tabel 4

Descriptive Statistic Skala Kepercayaan DiridanSkala Kecemasan Sosial

\begin{tabular}{|l|l|l|c|c|c|}
\hline \multicolumn{1}{|c|}{ Variabel } & N & Iean & Std.Deviation & Iinimum & Iaximum \\
\hline Kepercayaan Diri & 54 & 4,72 & 12,694 & 56 & 109 \\
\hline Kecemasan Sosial & 54 & $\$ 4,70$ & 12,279 & 53 & 115 \\
\hline
\end{tabular}

Berdasarkan tabel 12 di atas dapat gambarankan bahwa 10 orang (16\%)narapidana menjelang bebas di bawah naungan Lembaga Pemasyarakatan Klas IIA Muaro Padang yang memilikiKepercayaan Diri yang rendah, 41 orang (64\%)narapidana menjelang bebas di bawah pembinaan Lembaga Pemasyarakatan Klas IIA Muaro Padang yang memilikiKepercayaan Diriyang sedang dan 13 orang (20\%) narapidana menjelang bebas di bawah pembinaan Lembaga Pemasyarakatan Klas IIA Muaro Padang yang memilikiKepercayaan Diri yang tinggi.

Sementara itu ada 7 orang (11\%)narapidana menjelang bebas di bawah pembinaan Lembaga Pemasyarakatan Klas IIA Muaro Padang yang memilikiKecemasan Sosialyang rendah, 51 orang $(80 \%)$ narapidana menjelang bebas di bawah pembinaan Lembaga Pemasyarakatan Klas IIA Muaro Padang yang memilikiKecemasan Sosialyang sedang dan 6 orang (9\%)narapidana menjelang bebas di bawah pembinaan Lembaga Pemasyarakatan Klas IIA Muaro Padang yang memilikiKecemasan Sosialyang tinggi.

Adapun sumbangan efektif dari variabel Kepercayaan Diri terhadap variabel Kecemasan Sosialsebesar sebersar 39\% hal ini dapat diartikan bahwa Kepercayaan Dirimampu memberikan kontribusi positif terhadap Kecemasan Sosial, sedangkan 61\% sisanya dipengaruhi oleh faktor-faktor lainnya. Beberapa faktor lainnya yang mempengaruhi Kecemasan Sosial yaitu pertama faktor kecenderungan biologis, kedua faktor stres, dan faktor traumatik sosial (Durand dalam Prawoto, 2010)

\section{KESIMPULAN 5.1 KESIMPULAN}

Berdasarkan hasil pengumpulan data dan analisis data yang dilakukan peneliti, maka dapat ditarik kesimpulan yang sekaligus merupakan jawaban dari tujuan penelitian. Berdasarkan hasil uji korelasi antara variabel Kepercayaan Diri dan Kecemasan Sosial didapatkan hasil bahwa terdapat hubungan negatif atau tidak searah antara variabel Kepercayaan Diri dan Kecemasan Sosial, artinya hipotesis diterima berarti semakin rendah Kepercayaan Diri narapidana menjelang bebas, maka semakin tinggi Kecemasan Sosial yang dimiliki oleh narapidana menjelang bebas begitu pula sebaliknya, semakin tinggi Kepercayaan Diri narapidana menjelang bebas, maka semakin rendah Kecemasan Sosial yang dimiliki oleh narapidana menjelang bebas tersebut.

Sumbangan efektif dari variabel Kepercayaan Diri terhadap Kecemasan Sosial sebesar $39 \%$ dan $61 \%$ lagi ditentukan oleh sumbangan variabel lain.

\section{DAFTAR PUSTAKA}

Andriawita, Siti. 2012. Hubungan Konsep Diri Dengan Kecemasan Narapidana Menghadapi Masa Depan Di Lembaga Permasyarakatan Wanita Malang. Skripsi. Universitas Islam Negeri Maulana Malik Ibrahim Malang.

Anggraini, Helen Septi. 2015. Hubungan Antara Kepercayaan Diri Dan Dukungan Sosial Dengan Kecemasan Sosial Pada Narapidana Anak Di Lapas Klas IIB Pekanbaru. Skripsi. Universitas Islam Negeri Sultan Syarif Kasim Riau Pekanbaru.

Arikunto. 2010. Prosedur Penelitian: Suatu Pendekatan Praktik. Yogyakarta: Rineka Cipta.

Astuti, Juli. 2008. Pembinaan Sholat Terhadap Narapidana di Lembaga Permasyarakatan Klas IIA Yogyakarta. Skripsi. Universitas Islam Negeri Sunan Kalijaga Yogyakarta.

Azwar, Saifudin. 2013. Metode Penelitian. Yogyakarta : Pustaka Pelajar. 2012. Penyusunan skala psikologi. Yogyakarta : Pustaka Pelajar.

Baltaci, O., \& Hamarta, E. (2013). Analizing The Relationships Between Social Anxiety, Social Support And Problem Solving. Education and Science, 2013 Vol 38 No 167. 


\section{Darma Syahrullah Ekajaya,Jufriadi \\ Jurnal PSYCHE 165 Vol 12 No 1 (2019) 93-102}

Ernawati, Yuyun. dkk. 2012.Hubungan Dukungan Sosial dengan Kepercayaan Diri Pada Masa Kanakkanak Akhir di Sekolah Dasar Negeri Jember Lor 1 Kecamatan Patrang Kabupaten Jember. Artikel Ilmiah Hasil Penelitian Mahasiswa2012. Universitas Jember.

Ghufron, M. Nur \& Rini Risnawati S. 2014. Teori-Teori Psikologi. Jogjakarta: Ar-Ruzz Media

La Greca, A.M. \& Lopez, N. 1998. Social Anxiety AmongAdolescents: Linkages With Peer Relations And Friendships. Journal Of Abnonnal Child Psychology, Vol 26 No 2, 83-94.

Nainggolan, Togiaratua. 2011. Hubungan Antara Kepercayaan Diri Dengan Kecemasan Sosial Pada Pengguna Napza: Penelitian di Balai Kasih Sayang Parmadi Siwi. Sosiokonsepsia, Vol. 16 No. 02.

Nugroho, Henricus Yudianto Agung. 2015. Hubungan Konsep Diri Dan Kecemasan Narapidana Menjelang Bebas Di Lembaga Permasyarakatan Klas IIA Wirogunan Yogyakarta. Skripsi. Unveritas Sanata Dharma Yogyakarta.

Prawoto, Yulius Beny. 2010. Hubungan Antara Konsep Diri Dengan Kecemasan Sosial Pada Remaja Kelas XI Sma Kristen 2 Surakarta. Skripsi. Universitas Sebelas Maret Surakarta.

Priyatno, Duwi. 2008. Mandiri Belajar SPSS. Yogyakarta: Mediakom.

Puspitasari, Mega Ayu. 2014. Hubungan Antara Pengalaman Shalat Tahajud Dengan Kepercayaan Diri Menghadapi Ujian Nasional Pada Siswa Kelas XII MA Nurul Ummah Kotagede Yogyakarta Tahun Pembelajaran 2013/2014. Skripsi. Universitas Islam Negeri Sunan Kalijaga Yogyakarta.

Putri, Dewi Eka. dkk. Hubungan Dukungan Sosial dengan Tingkat Kecemasan Narapidana di Lembaga Pemasyarakatan Klas II A Muaro Padang Tahun 2014. Ners Jurnal Keperawatan, Volume 10. No 1, Oktober 2014 : 118 - 135.

Rosita, Herni. 2012. Hubungan Antara Perilaku Asertif Dengan Kepercayaan Diri Pada Mahasiswa. Skripsi. Universitas Gunadarma.

Sugiyono. 2013. Metode Penelitian Kuantitatif Kualitatif dan R\&D. Bandung: Alfabeta.

Swasti, Idei Khurnia \& Wisjnu Martani. 2013. Menurunkan Kecemasan Sosial melalui Pemaknaan Kisah Hidup. Jurnal Psikologi Volume 40, No. 1, Juni 2013: 39 - 58.

Syamsiah, Nur. 2010. Hubungan antara Persepsi Anak Terhadap Perhatian Orang Tua dan Intensitas Komunikasi Interpersonal dengan Kepercayaan Diri pada Remaja Difabel. Thesis. Universitas Muhammadiyah Surakarta

Widjaja, Jeanita Deli. 2014. Program Berani : CBT Berbasis Internet Untuk Menurunkan Kecemasan Sosial. Thesis. Universitas Gadjah Mada Yogyakarta.

Zuhro, Mayulis. 2011. Hubungan Kecerdasan Emosional Dengan Harga Diri Pada Narapidana Remaja Di Lembaga Pemasyarakatan Anak Blitar. Skripsi. Universitas Muhammadiyah Malang. 